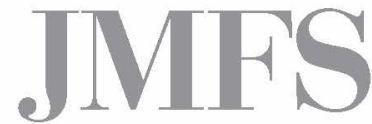

Journal of Management and Financial Sciences
Volume X

Issue 29 (September 2017)

pp. $143-157$

Warsaw School of Economics

Collegium of Management and Finance

Piotr Komorowski, Dariusz Filip

Department of Finance, Institute of Sociology,

Faculty of History and Social Sciences

Cardinal Stefan Wyszyński University in Warsaw

\title{
Information and Statistical Efforts of Selected Safety Network Institutions in the Area of Financial System Stability
}

\begin{abstract}
Financial system stability is considered a public good. The main role of the financial safety network is to stabilise the system. Information and statistical activities of institutions which belong to the safety network are the tools which may improve the stability. We need to stress that most decisions are based on information, in particular decisions on investment or speculation, hence by providing information and statistical data these institutions indirectly enhance the overall stability of the system. An overview and analysis of selected studies addressing financial system stability helped the authors draw theoretical and practical conclusions as to the stability itself and the impact of information and statistics upon its improvement.
\end{abstract}

Keywords: financial system stability, safety network, economic crisis, financial crisis JEL Code: G100 


\section{Introduction}

Financial system stability became a real issue in the late 20 th century due to a series of financial crises. Before the latter occurred, safety mechanisms in financial systems were not very much sophisticated and central banks focused on statutory activities, mainly on monitoring inflation. The current relevance of the subject is confirmed by the approach of top management of the National Bank of Poland (NBP), according to which maintaining financial system stability, especially against potential shocks and problems experienced by some financial institutions, is the priority challenge for banks ${ }^{1}$.

This study provides an overview of information and statistical efforts of institutions within the safety network, such as: the International Monetary Fund, European Central Bank, and National Bank of Poland. These efforts often translate into reports throwing light on the situation from different angles, which are major sources of knowledge to market participants about the condition of the financial system. By providing such information, indispensible to make informed investment decisions, information and statistics related activities of these institutions indirectly contribute to the enhanced overall stability of the system. For obvious reasons pertaining to available space, secondary research on financial system stability included in this paper has been restricted to an introductory overview ${ }^{2}$. The description of the tools and methods applied to assess the stability of a banking system, often encountered in related studies, requires a separate discussion. ${ }^{3}$ Selected indicators used in the text are complementary and indicative by nature.

The goal of the paper is to make an overview and assess information and statistical activities of selected institutions within the safety network geared at enhancing financial system stability. By analysing the content of reports drafted by major institutions involved in maintaining the stability of financial systems we will be able to compare the main objectives behind such reports, as well as similarities and differences in their approaches and data presentation. Moreover, the above findings will help draw the main conclusions about theoretical and practical aspects of the stability of the system.

1 Based on the President of NBP Adam Glapiński's address to the Polish Parliament on 20.07.2016.

2 For a wider overview of literature on the definition of financial system stability see: M. Zygierewicz. Stabilność finansowa. "Annales Universitatis Mariae Curie-Skłodowska", Sectio H, Vol. XLVII (3), Lublin 2013, pp. 685-695 and G. J. Schinasi, Defining Financial Stability, International Monetary Fund Working Paper, WP/04/187, 2004. p. 4 and subsequent.

3 For more about the assessment of banking system stability in Poland by NBP, BFG and KNF- the Polish Financial Supervision Authority see: W. Gradoń, Metody oceny stabilności systemu bankowego w Polsce, "Studia Ekonomiczne", Uniwersytet Ekonomiczny w Katowicach, No. 186, part 1 Innowacje, a wzrost gospodarczy. Part 1, Katowice 2014, pp. 254-267. 
The paper is composed of several essential parts. The first one provides a literature review on the financial system theory, its definition and the notion of stability. The second part examines information and statistical activities of the International Monetary Fund. In the third part we discuss the content of an NBP report on financial system stability. Finally, the fourth part describes the specificity of the financial stability assessment by the European Central Bank. The paper finishes with final conclusions.

\section{Literature Review: Notions Related to the Financial System and Its Stability}

Financial system stability has been explored on many occasions in specialist literature. The question concerns and covers various aspects of finance and the financial system. The scope of financial system stability should be taken as a starting point of the overview. To define the subject of our paper we should explain the notion of a financial system and then focus on its stability.

Financial system can be understood as a "set of logically linked organisational structures, legal acts, financial institutions and other elements that enable establishing financial relations in the real sector as well as in finance". A financial system comprises a chain of closely interrelated financial institutions, markets, instruments, services, practices, and transactions ${ }^{5}$.

By making reference to a financial system we need to take account of the systems theory, according to which a system unifies relatively independent elements that perform various functions vis-à-vis goals that are considered common ${ }^{6}$. The purpose is a central distinguishing factor essential for any system. At the same time, fundamental differences between financial systems in different countries lie in the hierarchy of goals.

Generally speaking, within any financial system money and capital are transferred between those who have accumulated financial surpluses and those who need higher liquidity ${ }^{7}$. A financial surplus is channelled by financial markets and intermediaries

4 S. Owsiak, Podstawy nauki finansów, PWF, Warszawa 2002, p. 233.

5 See A. Sullivan, S.M. Sheffin, Economics: Principles in action, Pearson Prentice Hall, New Jersey 2003, p. 551 and M. Zukowski, Instytucje tworzace infrastrukturę systemu bankowego [in:] Bankowośc, M. Zaleska, Beck, Warszawa 2013, pp. 57-72.

6 System features quoted after T. Kotarbiński, Traktat o dobrej robocie, Zakład Narodowy im. Ossolińskich Wydawnictwo Polskiej Akademii Nauk, Wrocław-Warszawa-Kraków-Gdańsk-Łódź 1982, p. 79:" method, i.e. a particular procedure, is a way to accomplish a complex act consisting in a specific choice and sequence of its components, planned and organised in such a way that it can be reproduced repeatedly."

7 A. Sullivan, S.M. Sheffrin, op.cit., p. 551. 
to those who suffer from financial shortages ${ }^{8}$. Thus, a financial system is the broadest term comprising the mechanism of flows of funds in the economy. Complexities of the system generate various difficulties resulting from simplifications, non-homogenous terminology and approaching various levels of market analysis as independent of changes and external factors. Ignoring links at different levels in the analysis of financial system stability may lead to incorrect conclusions.

Essential functions of the system are in principle identical in all economies. The classical approach distinguishes the following functions: monetary, capital redistribution, and supervisory ${ }^{9}$. However, due to differences in the size, complexity, applied technology, culture, policy or institutional mechanisms financial systems may differ a lot ${ }^{10}$. Hence, especially under dynamic changes and integrating processes taking place in financial markets, various analytical approaches to the system combined with the holistic approach in the analysis may provide complementary and useful information to possibly reliably reproduce real processes in the financial system against the analytical background. Different approaches to the financial system in specialist literature are presented in Box 1.

Knowing how the financial system, which impacts the economy, works is a condition for its smooth performance. It also encourages a reflection over its efficiency and effectiveness. Obviously, a properly operating and stable financial system is crucial for the growth of the economy of any country ${ }^{11}$. Independently of the approach, a financial system is decisive for the allocation of resources and building-up a modern economy ${ }^{12}$. Due to multidimensional and complex links between its elements and the financial environment, disturbances originating from any element of the system may undermine its overall stability. Thus, to define financial system stability we need to adopt a comprehensive approach.

Financial stability consists in a dynamic and lasting equilibrium experienced in interlinked financial markets ${ }^{13}$. Equilibrium means reducing emerging imbalances and coping with them before they have become dangerous. A similar definition is

8 F.S. Mishkin, The Economics of Money, Banking and Financial Markets, Harper Collins College Publishers, New York 1995, p. 21.

9 J. Ostaszewski (Ed.), Finanse, Difin, Warszawa 2008, pp. 22-23.

${ }^{10}$ R.C. Merton, The Financial System and Economic Performance, "Journal of Financial Services Research", Vol. 4, No. 4, Kluwer Academic Publishers, Harvard University, Boston 1990, p. 263.

${ }_{11}$ R.W. Ferguson, International Financial Stability, Centre for Economic Policy Research, Geneva 2007 p. 19.

12 For more in J.C. Berthelemy, A. Varudakis, Models of Financial Development and Growth, [in:] Financial Development and Economic Growth, N. Hermes, R. Lensink (Eds.), Routledge, New York 1996, pp. 7-29.

13 J.K. Solarz, Międzynarodowy system finansowy, Biblioteka Menedżera i Bankowca, Warszawa 2001, p. 195 and further. 
proposed in the Financial Stability Report, where financial system stability is characterised as a state in which the system operates efficiently on a continuous basis, even if unexpected, unfavourable and little likely disturbances occur at a substantial scale ${ }^{14}$.

\section{Box 1. Overview of approaches to the financial system}

\begin{tabular}{|c|c|c|c|}
\hline \multicolumn{2}{|c|}{ Analytical approach } & Characteristics & Vision of the financial system \\
\hline \multicolumn{2}{|c|}{ Institutional } & $\begin{array}{l}\text { Financial system depicted and } \\
\text { classified from the viewpoint of financial } \\
\text { institutions; additionally a selected } \\
\text { feature of institutions is often analysed } \\
\text { (e.g. competitiveness, investors' rights } \\
\text { protection, quality of financial regulations). }\end{array}$ & $\begin{array}{l}\text { Financial system as a set of specific } \\
\text { financial institutions classified in different } \\
\text { groups. }\end{array}$ \\
\hline \multirow[t]{2}{*}{$\begin{array}{l}\text { Narrow } \\
\text { functional }\end{array}$} & Monetary & $\begin{array}{l}\text { Financial system analysed primarily } \\
\text { in the context of provision of funds to the } \\
\text { real sector through the central bank and } \\
\text { commercial banks. }\end{array}$ & $\begin{array}{l}\text { Financial system as a mechanism } \\
\text { providing funds to the real economy. }\end{array}$ \\
\hline & $\begin{array}{l}\text { Based on } \\
\text { intermediation }\end{array}$ & $\begin{array}{l}\text { Financial system analysed against its } \\
\text { two major functions: intermediation } \\
\text { between its surplus and deficit actors and } \\
\text { transformation. }\end{array}$ & $\begin{array}{l}\text { Financial system as an intermediation } \\
\text { mechanism between surplus and deficit } \\
\text { actors of the real economy. }\end{array}$ \\
\hline \multicolumn{2}{|c|}{ Broad functional } & $\begin{array}{l}\text { Financial system analysed from the } \\
\text { viewpoint of its functions. Supporters } \\
\text { of such an approach argue in favour of } \\
\text { its relative stability and comparability of } \\
\text { functions of national financial systems. }\end{array}$ & $\begin{array}{l}\text { The notion of financial system covers } \\
\text { a network of financial markets, } \\
\text { intermediaries and other institutions, } \\
\text { which help deliver all financial plans } \\
\text { of households, enterprises and the } \\
\text { government. }\end{array}$ \\
\hline \multicolumn{2}{|l|}{ Systemic } & $\begin{array}{l}\text { Financial system described as relations } \\
\text { between its components and their } \\
\text { impact upon the system (the idea of } \\
\text { complementarity and coherence). }\end{array}$ & $\begin{array}{l}\text { Financial system as an orderly set of } \\
\text { complementary and possibly coherent } \\
\text { elements or subsystems. }\end{array}$ \\
\hline
\end{tabular}

Source: A. Matysek-Jędrych, System finansowy - definicja i funkcje, "Bank i Kredyt" no. 10/2007, Warszawa 2007, p. 40.

In another approach, financial system stability means the stability of its two fundamental components: financial institutions and financial markets. The stability of financial institutions takes place when they are able to perform their contractual obligations continuously, trouble-free and without any external assistance. Financial markets stability is interpreted in the context of stable prices of assets ${ }^{15}$.

A financial system is stable when it is able to withstand shocks without giving way to the accumulation of processes that might adversely affect the allocation of savings

\footnotetext{
${ }^{14}$ Financial Stability Report, February 2016, Financial Stability Department, NBP, Warszawa 2016, p. 3.

${ }^{15}$ K. Mitręga-Niestrój, Niestabilność finansowa i jej źródła we wspótczesnym świecie, [in:] Zarzadzanie instytucjami finansowymi w niestabilnym otoczeniu gospodarczym, M. Capiga, G. Szustak (Eds.), "Studia Ekonomiczne", Uniwersytet Ekonomiczny w Katowicach, No. 171, Katowice 2014, p. 10.
} 
into investments and the processing of payments in the economy ${ }^{16}$. To maintain the allocation function and prevent payment backlogs, as well as to preserve a broadly understood equilibrium under conditions of shocks that may lead to crises, the financial system is equipped with self-regulation and recovery mechanism ${ }^{17}$. Hence, we may observe that stability is the effect of the smooth performance of preventive and remedy tools. They prevent shocks originating from a single market actor to propagate and get transmitted ${ }^{18}$, i.e., to avoid a situation when the risk connected with operations of individual actors, if materialised, might lead to systemic risk.

Financial system stability may also be interpreted as a public good ${ }^{19}$. Loss of trust in the financial system may entail its crisis and the crisis of the economy in question ${ }^{20}$. The synergy between the level of regulations, binding market solutions and approved principles of financial markets organisation and the development of the financial market is crucial for stability ${ }^{21}$. Its absence undermines stability as we have seen it, e.g., during the latest global crisis. On top of that, it seems that the domination of big and systemically important financial institutions, the so called SIFIs, poses a challenge to stability ${ }^{22}$. That is why it is analysed by central institutions, including those from the financial system safety network ${ }^{23}$.

Considering the above, the analysis of security and stability of the financial system suggests that working out and maintaining a proper balance between the development of the financial system and the regulatory framework that directly or

16 T. Paddoa-Schioppa, Central Banks and Financial Stability: Exploring a Land in between. Second ECB Central Banking Conference: The Transformation of the European Financial System, 24 and 25 October 2002, EBC, Frankfurt am Main 2002, p. 20.

17 Regulatory risk is the risk of changes in the legal business environment, after: Z. Korzeb, Wptyw otoczenia regulacyjnego na liczbe fuzji i przejęć w polskim sektorze bankowym, "Bezpieczny Bank", No. 3(64) 2016, Bankowy Fundusz Gwarancyjny, Warszawa 2016, p. 48.

${ }^{18}$ For more about infection with a crisis and its transmission see P. Komorowski, Przebieg kryzysu gospodarczego w wymiarze cyklu życia, [in:] Wiedza i bogactwo narodów, Kapital ludzki, globalizacja i regulacja w skali światowej, Ekonomia i finanse, R. Bartkowiak, P. Wachowiak (Eds.), OW SGH, Warszawa 2013, pp. 281-291.

19 A. Alińska, K. Wasiak, Czy stabilność systemu finansowego można uznać za dobro publiczne, "Studia Ekonomiczne". Zeszyty Naukowe Uniwersytetu Ekonomicznego w Katowicach, No. 198, part 1, Katowice 2014, pp. 13-31.

${ }_{20}$ H. Zukowska, M. Żukowski, System gwarancji depozytów bankowych osób fizycznych w Rosji, "Bezpieczny Bank", No. 3(45) 2011, Bankowy Fundusz Gwarancyjny, Warszawa 2011, p. 59.

${ }^{21}$ A. Alińska, Sieć bezpieczeństwa finansowego jako element stabilności funkcjonowania sektora bankowego, Kwartalnik Kolegium Ekonomiczno-Społecznego "Studia i Prace" No. 4(8)/2011, OW SGH, Warszawa 2011, p. 88.

22 Z. Korzeb, Zagraniczne inwestycje kapitatowe banków komercyjnych działajacych w polskim sektorze bankowym, "Annales Universitatis Mariae Curie-Skłodowska". Sectio H, Oeconomia 48/1, Vol. XLVIII (1), Lublin 2014, p. 101.

${ }_{23}$ G. Caprio, P. Bacchetta, Handbook of Safeguarding Global Financial Stability: Political, Social, Cultural, and Economic Theories and Models, Academic Press, Boston, 2012 p. 225 and subsequent. 
indirectly targets its entities is crucial ${ }^{24}$. Under present economic conditions, such as, e.g., the global polarisation of production and consumption, surpluses and deficits, savings and debt, economic growth and stagnation, as well as growing market risk, increased supply of money and political and social tensions, financial system stability is paramount and apparently increasingly more difficult to maintain.

\section{Information and Statistical Activities of the International Monetary Fund}

The International Monetary Fund develops many analytical initiatives designed to improve the transparency of financial systems and their resistance to crises through regular risk assessment exercises. Market data is also used by the IMF in its statutory activities, including the drafting of the Global Financial Stability Report. The report assesses the global financial system stability as well as individual financial markets. Moreover, it provides detailed analyses of emerging markets against the background of global processes. It focuses on current market conditions and takes account of systemic circumstances ${ }^{25}$. Each edition of the report develops issues highlighted in another IMF report, World Economic Outlook.

The report comes with a vast database of primary data, which enables mapping and processing numerical data, generating comparisons and graphic representations. The data is aggregated at different levels, from sectoral data for individual countries to regional or global data.

Under another information and statistical initiative, the IMF reports the so called Financial Soundness Indicators. The database based on them seeks to provide information about the financial standing of financial institutions, the non-financial sector, and households in individual countries. Indicators are divided into groups that describe the performance of deposit institutions, other financial institutions, non-financial enterprises, households, financial market liquidity, and the real estate market. The data is provided by countries on a voluntary basis. Table 1 presents selected information about the stability of the financial system in Poland ${ }^{26}$.

${ }_{24}$ Based on A. Alińska, Sieć bezpieczeństwa finansowego jako element stabilności funkcjonowania sektora bankowego, Kwartalnik Kolegium Ekonomiczno-Społecznego "Studia i Prace" No. 4(8)/2011, OW SGH, Warszawa 2011, p. 87.

$25 \mathrm{https} / /$ www.imf.org/external/pubs/ft/gfsr/index.htm, accessed on 25.09.2016.

${ }_{26}$ Financial Soundness Indicators, Compilation Guide, March 2006, https://www.imf.org/external/ pubs/ft/fsi/guide/2006/index.htm, accessed on 22.09.2016. 
Table 1. Selected indicators of financial stability of the banking system in Poland

\begin{tabular}{|l|r|r|r|r|r|r|}
\hline \multicolumn{1}{|c|}{ Indicator/year } & \multicolumn{1}{c|}{2010} & 2011 & 2012 & 2013 & 2014 & 2015 \\
\hline Solvency ratio & 13.9 & 13.1 & 14.8 & 15.7 & 14.7 & 16.5 \\
\hline Equity to assets & 8.2 & 7.8 & 8.7 & 9.1 & 8.9 & 9.4 \\
\hline Impaired loans to all loans & 4.9 & 4.7 & 5.2 & 5.0 & 4.8 & 4.3 \\
\hline Provisions for impaired loans & 72.5 & 71.8 & 68.2 & 67.8 & 69.3 & 69.6 \\
\hline Return on assets & 1.0 & 1.3 & 1.2 & 1.1 & 1.1 & 0.8 \\
\hline Return on equity & 13.3 & 16.1 & 14.0 & 12.1 & 12.3 & 9.5 \\
\hline
\end{tabular}

Source: the authors' own calculations based on the IMF data, Global Financial Stability Report, April 2016.

Despite strong criticism of the IMF's activities ${ }^{27}$, databases and specialist reports are extensive sources of information. Once again we need to stress that recipients of such information are expected to acquire necessary data and be able to assess it and to reject unnecessary information, i.e. to filter the so called information noise.

\section{NBP Financial Stability Report}

The NBP Financial Stability Report [PL: Raport o stabilności systemu finansowego] is an analysis of the financial system in Poland published every six months ${ }^{28}$. The goal of the Report is to present the results of the analyses of financial system stability, including the assessment of its robustness to potential disturbances, and to inform financial market players about the condition of the system and potential risks. Such initiatives improve the understanding of market mechanisms under specific economic conditions, which may favour system stability. The report in question highlights some relevant theses, which may be used to sketch the idea of stability. They $\operatorname{are}^{29}$ :

- financial system stability is the pre-condition for long-term economic growth;

- banking sector stability is particularly relevant for maintaining financial system stability in Poland since assets of this sector account for two thirds of the overall system and banks are fundamental for financing the economy and for the flow of financial resources and equity;

27 The IMF has been heavily criticised by many circles, including economists. The voice of Joseph Stiglitz, Nobel Prize laureate in economics seems to be the best heard in discussions, inter alia in: J.E. Stiglitz, Globalization and Its Discontents, Washington, DC, W.W. Norton \& Co., 2002.

28 The NBP Board decided that the Report on financial system stability will be published in December and June every year to provide data for periods the most frequently used by analysts, i.e. the first half and the end of the year; after http://www.nbp.pl/, accessed on 13.08.2016.

${ }^{29}$ Raport o stabilności systemu finansowego [Financial Stability Report], February 2016, Financial Stability Department, NBP, Warszawa 2016, p. 3. 
- financial system stability is closely linked with the tasks entrusted to the central bank, which is part of the system responsible, inter alia, for the stability of prices, minimising systemic risk and organisation of cash settlements and is involved in drafting monetary, regulatory and supervision policies, which impact financial stability and growth.

The logical structure of the survey is the following. Conditions in which financial institutions operate are analysed in the introductory section. In general, the report describes processes taking place in the broadly understood macroeconomic environment and sketches phenomena decisive for the situation in individual markets (monetary, foreign exchange, bonds, stock, and real estate) in the previous period ${ }^{30}$.

As stated in the introduction, the banking sector is the most important for the stability of the financial system in Poland, which is why the report discusses it broadly. Priority areas studied in the report include: bank lending activities, loan quality in the context of credit risk, market risk, structure of financing and liquidity risk, sector earnings, capital position of banks, and the market value analysis for banks. The above analyses are descriptive and illustrated with diagrams that present corresponding data. They are also substantiated with tables of over thirty indicators that describe the situation in the banking sector, especially in domestic commercial banks and cooperative banks. These indicators include: return on assets, return on equity, net interest margin, operating costs to net income from banking activity, burden of charges to provisions for impaired loans to net income from banking activities, the loan growth rate, impaired loan ratios, charges to provisions for impaired loans to net value of loans, the funding gap, capital ratios, and the liquidity ratio. Values of examples of indicators discussed in the abovementioned report for the last 5 quarters are presented in Table $2^{31}$.

Table 2 provides indicators reflecting the financial standing of the banking sector, domestic commercial banks and cooperative banks. Further the report analyses the condition of credit unions (Polish abbr. SKOK). Their liquidity and profitability is examined based on the indicators that inform about, inter alia, assets held by these institutions, their structure and liquidity, solvency, financial result, as well as the deposits and loans portfolio ${ }^{32}$.

${ }^{30}$ Financial Stability Report, February 2016, Financial Stability Department, NBP, Warszawa 2016, pp. 19-35.

${ }^{31}$ Financial Stability Report, February 2016, Financial Stability Department, NBP, Warszawa 2016, pp. 37-81.

${ }^{32}$ Financial Stability Report, February 2016, Financial Stability Department, NBP, Warszawa 2016, pp. 83-88. 
Table 2. Selected indicators reflecting the condition of groups of entities in the banking sector

\begin{tabular}{|c|c|c|c|c|c|c|}
\hline \multirow{2}{*}{ in $\%$} & \multirow{2}{*}{ entities } & \multicolumn{2}{|c|}{2014} & \multicolumn{3}{|c|}{2015} \\
\hline & & Q3 & Q4 & Q1 & Q2 & Q3 \\
\hline \multirow{3}{*}{ Return on Assets (ROA) } & banking sector & 0.82 & 0.75 & 0.73 & 0.65 & 0.51 \\
\hline & domestic commercial banks & 1.15 & 1.11 & 1.09 & 1.01 & 0.95 \\
\hline & cooperative banks & 0.82 & 0.75 & 0.73 & 0.65 & 0.51 \\
\hline \multirow{3}{*}{ Return on Equity (ROE) } & banking sector & 12.2 & 11.8 & 11.8 & 10.7 & 10 \\
\hline & domestic commercial banks & 12.4 & 12 & 12 & 11 & 10.3 \\
\hline & cooperative banks & 8.9 & 8.3 & 8.1 & 7.2 & 5.7 \\
\hline \multirow{3}{*}{$\begin{array}{l}\text { Net Interest Margin } \\
\text { (NIM) }\end{array}$} & banking sector & 2.61 & 2.5 & 2.41 & 2.3 & 2.23 \\
\hline & domestic commercial banks & 2.59 & 2.46 & 2.37 & 2.26 & 2.2 \\
\hline & cooperative banks & 3.4 & 3.35 & 3.27 & 3.26 & 3.05 \\
\hline \multirow{3}{*}{$\begin{array}{l}\text { Operating costs to net } \\
\text { income from banking } \\
\text { activity (CTI) }\end{array}$} & banking sector & 52.1 & 51.8 & 51.9 & 53.5 & 55 \\
\hline & domestic commercial banks & 49.6 & 49.3 & 49.3 & 50.9 & 52.5 \\
\hline & cooperative banks & 70.1 & 70 & 70.7 & 72 & 73.3 \\
\hline \multirow{3}{*}{ Funding gap } & banking sector & 8.7 & 6.9 & 6.8 & 8.7 & 6.7 \\
\hline & domestic commercial banks & 11.4 & 9.7 & 9.9 & 11.4 & 9.1 \\
\hline & cooperative banks & -37.6 & -40.2 & -43.2 & -37.6 & -36.7 \\
\hline \multirow{3}{*}{ Total capital ratio } & banking sector & 14.9 & 14.7 & 14.9 & 15.3 & 15.6 \\
\hline & domestic commercial banks & 14.9 & 14.6 & 14.8 & 15.3 & 15.6 \\
\hline & cooperative banks & 15.8 & 15.7 & 15.6 & 15.9 & 15.6 \\
\hline \multirow{3}{*}{$\begin{array}{l}\text { Financial leverage } \\
\text { (multiple) }\end{array}$} & banking sector & 11.13 & 11.27 & 11.4 & 11.09 & 11.21 \\
\hline & domestic commercial banks & 11.13 & 11.26 & 11.38 & 11.09 & 14.2 \\
\hline & cooperative banks & 10.88 & 11.12 & 11.45 & 10.87 & 11.02 \\
\hline
\end{tabular}

Source: the authors' own calculations based on tables from Sections 2.8., 2.9., and 2.10. of the NBP Financial Stability Report, February 2016, Financial Stability Department, NBP, Warszawa 2016, pp. 79-81.

The report on financial system stability also discusses the performance of noncredit financial institutions classified as insurance companies, investment funds management companies and investment funds, as well as pension fund management companies and open pension funds. Besides, it investigates inter-sector linkages of non-credit financial institutions.

When it comes to security, the report addresses the assessment of risk, including systemic risk, to the stability of the domestic financial system, especially the standing of the banking sector, the dominant component of the Polish financial system. The analysis includes simulations and stress tests. Finally, the report makes key 
recommendations for the maintenance of financial system stability. Synthetically, they can be summarised in several bullet points below ${ }^{33}$ :

- to avoid measures that might put the stability of the system at risk, primarily to reduce the risk of operations that impact FX mortgage portfolios, the risk of imposing additional taxes on financial institutions and the risk of regulatory new requirements and capital burden;

- further integrate cooperative and associating banks into institutional protection systems (IPS) and timely implementation of solutions that ensure their full operability;

- further restructuring of SKOK aimed at boosting the efficiency of the credit unions and increasing their capital reserves;

- to take account of potential increases in interest rates in banks lending policies, in particular for long-term loans;

- to pursue a prudential loan policy vis-à-vis the commercial real estate sector (offices, retail and service space);

- to take particular care of adequate assets liquidity in open-ended investment funds. The NBP Financial Stability Report is an elaborate document, which may be a source of comprehensive information about the stability of the financial system in Poland. Its great advantage is the attached database of source data available in spread sheets that enable their further processing.

\section{ECB Financial Stability Review}

The last one on the list of discussed studies is the Financial Stability Review published by the European Central Bank since 2004 every six months. The report examines potential sources of risk and threats to the financial stability in the eurozone. Similarly to the NBP report discussed in Section 3 above, the Review is intended to promote knowledge about issues relevant to ensure financial system stability, in this case in the euro area, in the financial sector and to a broader stakeholder group. Thus, the document, being the source of information about the risks and weaknesses of the financial system, is a tool designed to prevent financial crises ${ }^{34}$.

Remarkably, the review stresses that financial stability is understood as a state whereby the build-up of systemic risk is prevented. Systemic risk can derive from

33 Financial Stability Report, February 2016, Financial Stability Department, NBP, Warszawa 2016, pp. 133-135.

${ }^{34}$ https://www.ecb.europa.eu/pub/fsr/html/index.en.html, accessed on 20.09.2016. 
three sources: the endogenous build-up of financial imbalances, usually associated with the booming business cycle, large aggregate shocks hitting the economy or the financial system, and mechanisms that transmit crises as a result of contagion effects ${ }^{35}$. We need to stress that these terms, even if often used interchangeably to describe the propagation of crisis in the economy, put accents differently and have been explicitly defined and described in literature ${ }^{36}$.

The above understanding of financial system stability in a way determines the analytical approach. Main substantial aggregates of the analysis and its layout reflect the logic of the mechanism, which proves that a crisis may come "from the outside", disseminate across financial markets and financial sector stability is a safety buffer for the real economy.

Financial sector stability is composed of:

- an analysis of the macro-financial and credit environment considering, inter alia, external and political risks as well as the situation of households;

- an overview of financial markets stability;

- an analysis of financial institutions' stability, including financial standing, stress tests and a synthesis of changes in the regulatory framework.

The report is highly informative when it comes to financial system stability because it is drafted from the perspective of the entire euro area. It means the analysis does not target the circumstances of individual countries but financial systems of the area comprising countries using the same currency. The report does not provide numerical data, which to an extent restricts the analysis and makes it difficult for a reader to further process the source material.

\section{Conclusion}

Financial system stability is desired and necessary for economic growth. Its loss may trigger the domino effect when interlinked risks materialise or come as the effect of such an impulse. Thus, efforts made to maintain stability increasingly more often turn into tools used by safety network institutions. Stability is also the subject of studies and analyses performed by analytical departments of such institutions.

35 V. Constâncio, ECB Vice-President in Financial Stability Review, May 2016, EBC, Frankfurt 2016, p. 3 .

${ }^{36}$ For more about the specificity of crisis development, see, e.g.: P. Komorowski, Przebieg kryzysu gospodarczego w wymiarze cyklu życia, [in:] Wiedza i bogactwo narodów, Kapital ludzki, globalizacja i regulacja w skali światowej, Ekonomia i finanse, R. Bartkowiak, P. Wachowiak (Eds.), OW SGH, Warszawa 2013, pp. 281-291. 
Financial system stability, i.e., its resilience to destabilising occurrences determines the overall robustness of the economy. Financial systems provide a safety buffer, which restricts systemic risk caused by crisis-inducing impulses generated by individual entities.

The literature review has led us to the following theoretical conclusions on financial system stability:

- financial system stability is a public good;

- a properly functioning financial system, also its stability, is crucial for the growth of any economy;

- disturbances originating from any component of the financial system may undermine its overall stability, which is why we need to take a systemic approach to the analysis of financial system stability;

- the stability of financial markets results from the synergy of regulatory framework, binding market solutions and principles of financial market arrangements and the financial market development.

As already noted stability is the ability of financial system institutions to constantly and sustainably perform their functions. Stability is the subject of studies of institutions within the safety network. Based on their overview we have drawn the following practical conclusions:

- as assumed by safety network institutions, the knowledge about issues vital for the stability of the financial system promoted among financial market actors enhances the stability of markets;

- informative relevance of documents produced by safety network institutions is substantial when reports are made available together with source data;

- substantive value of reports remains in line with their specificity, i.e.:

- those which tackle regional or global markets do not inform about the circumstances in individual countries, hence their applicability in micro-analyses is rather limited;

- those which refer to the stability of individual markets or economies are little useful for macro- or global analyses.

We need to bear in mind that in particular investment and speculation decisions are taken based on available information. Information and statistical efforts of financial institutions brought together in a safety network exert an impact upon participants to financial markets. They do so by generating reliable market data and making it available for further analyses. The final outcome should improve financial system stability in the common interest of its actors and stakeholders. 


\section{Bibliography}

1. Alińska A., Sieć bezpieczeństwa finansowego jako element stabilności funkcjonowania sektora bankowego, Kwartalnik Kolegium Ekonomiczno-Społecznego "Studia i Prace" No. 4(8)/2011, OW SGH, Warszawa 2011.

2. Alińska A., Wasiak K., Czy stabilność systemu finansowego można uznać za dobro publiczne, "Studia Ekonomiczne". Zeszyty Naukowe Uniwersytetu Ekonomicznego w Katowicach, No. 198, part 1, Katowice 2014.

3. Berthelemy J.C., Varudakis A., Models of Financial Development and Growth, [in:] Financial Development and Economic Growth, N. Hermes, R. Lensink (Eds.), Routledge, New York 1996.

4. Caprio G., Bacchetta P., Handbook of Safeguarding Global Financial Stability: Political, Social, Cultural, and Economic Theories and Models, Academic Press, Boston, 2012.

5. Constâncio V., Wiceprezes EBC w Financial Stability Review, May 2016, EBC, Frankfurt 2016.

6. Ferguson R.W., International Financial Stability, Centre for Economic Policy Research, Geneva 2007.

7. Gradoń W., Metody oceny stabilności systemu bankowego w Polsce, "Studia Ekonomiczne", Uniwersytet Ekonomiczny w Katowicach, No. 186, part 1 Innowacje a wzrost gospodarczy. Part 1, Katowice 2014.

8. Komorowski P., Przebieg kryzysu gospodarczego w wymiarze cyklu życia, [in:] Wiedza i bogactwo narodów, Kapitał ludzki, globalizacja i regulacja $w$ skali światowej, Ekonomia i finanse, R. Bartkowiak, P. Wachowiak (Eds.), OW SGH, Warszawa 2013.

9. Kotarbiński T., Traktat o dobrej robocie, Zakład Narodowy im. Ossolińskich Wydawnictwo Polskiej Akademii Nauk, Wrocław-Warszawa-Kraków-Gdańsk-Łódź 1982.

10. Korzeb Z., Wpkyw otoczenia regulacyjnego na liczbe fuzji i przejęć w polskim sektorze bankowym, "Bezpieczny Bank", No. 3(64) 2016, Bankowy Fundusz Gwarancyjny, Warszawa 2016.

11. Korzeb Z., Zagraniczne inwestycje kapitałowe banków komercyjnych działających w polskim sektorze bankowym, "Annales Universitatis Mariae Curie-Skłodowska". Sectio H, Oeconomia 48/1, Vol. XLVIII (1), Lublin 2014.

12. Merton R.C., The Financial System and Economic Performance, "Journal of Financial Services Research", Vol. 4, No. 4, Kluwer Academic Publishers, Harvard University, Boston 1990.

13. Mishkin F.S., The Economics of Money, "Banking and Financial Markets", Harper Collins College Publishers, New York 1995. 
14. Mitręga-Niestrój K., Niestabilność finansowa i jej źródła we współczesnym świecie, [in:] Zarządzanie instytucjami finansowymi w niestabilnym otoczeniu gospodarczym, M. Capiga, G. Szustak (Eds.), Studia Ekonomiczne, Uniwersytet Ekonomiczny w Katowicach, No. 171, Katowice 2014.

15. Ostaszewski. J., Finanse, Difin, Warszawa 2008, pp. 22-23.

16. Owsiak S., Podstawy nauki finansów, PWF, Warszawa 2002.

17. Paddoa-Schioppa T., Central Banks and Financial Stability: Exploring a Land in between. Second ECB Central Banking Conference: The Transformation of the European Financial System, 24 and 25 October 2002, EBC, Frankfurt am Main 2002.

18. Schinasi G.J., Defining Financial Stability, International Monetary Fund Working Paper, WP/04/187, 2004.

19. Solarz J.K., Międzynarodowy system finansowy, Biblioteka Menedżera i Bankowca, Warszawa 2001.

20. Stiglitz J.E., Globalization and Its Discontents, Washington, DC, W.W. Norton \& Co., 2002.

21. Sullivan A., Sheffin S.M., Economics: Principles in Action, Pearson Prentice Hall, New Jersey 2003.

22. Zygierewicz M., Stabilność finansowa. "Annales Universitatis Mariae Curie-Skłodowska", Sectio H, Vol. XLVII (3), Lublin 2013.

23. Żukowski M., Instytucje tworzace infrastrukture systemu bankowego [in:] Bankowość, M. Zaleska, Beck, Warszawa 2013

24. Żukowska H., Żukowski M., System gwarancji depozytów bankowych osób fizycznych w Rosji, "Bezpieczny Bank", Nr 3(45) 2011, Bankowy Fundusz Gwarancyjny, Warszawa 2011.

25. Financial Soundness Indicators, Compitation Guide, March 2006, https://www.imf. org/external/pubs/ft/fsi/guide/2006/index.htm, accessed on 22.09.2016.

26. Raport o stabilności systemu finansowego [Financial Stability Report], February 2016, Financial Stability Department, NBP, Warszawa 2016.

27. https://www.ecb.europa.eu/pub/fsr/html/index.en.html, accessed on 20.09.2016.

28. https://www.imf.org/external/pubs/ft/gfsr/index.htm, accessed on 25.09.2016. 